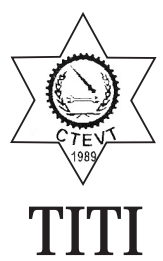

Journal of

Training and Development

2020, Volume 5

ISSN: 2392-456X(Print)

DOI: https://doi.org/10.3126/jtd.v5i0.33888

ISSN: 2392-4578(Online)

\title{
TVET Programs in Nepal: Issue of Access and Relevancy
}

\author{
Manoj Sharma Neupane \\ Labour Market Analysist, TVET Professional \\ Corresponding Email: nmanojsharma@yahoo.com
}

\begin{abstract}
Equitable access of market relevant TVET (Technical and Vocational Education and Training) programs is the first and foremost pre-condition to get the desired outcomes from TVET. The access and relevancy of TVET programs in Nepal are usually questionable. The major objectives of this paper is to analyze the access and relevancy of presently available long term TVET programs and identify its gap with the market demand. The analytical approach adopted for this paper is mainly quantitative and is based on the analysis of micro data of TVET institutes affiliated with Council for Technical Education and Vocational Training (CTEVT) and Central for Education and Human Resource Development (CEHRD) with corresponding information of their location, programs and enrolment capacity. Likewise, review of various other literatures including, journal articles, workshops proceedings, research reports etc. are also taken into reference. Significant variation is found between the ratio of district level enrolment capacity of long-term TVET programs to corresponding number of SEE graduates of the districts which raises question on the equitable access of TVET programs in terms of geography. Based on the analysis made in this paper, health related programs are justified as over accessed programs whereas a clear gap can be observed in the supply mechanism of TVET regarding tourism and agriculture sector. Attention is therefore needed to promote TVET programs in agriculture and tourism related sectors both in quality and quantity in order to mitigate existing mismatch between demand and supply.
\end{abstract}

Keywords: Access, Relevancy, TVET, Productivity, Labour Market

\section{Introduction}

Labor productivity is one of the major components to enhance total factor productivity of the economy. Similarly, systematic development of TVET sub sector (sectors concerns with skills, knowledge and technology) is instrumental in enhancing the productivity of workforce which ultimately contributes to increase total factor productivity and production of a nation (Neupane, 2013). The first and foremost pre-condition to get the desired outcomes from TVET is to make equitable access of market-relevant TVET Programs.

In recent past, lot of efforts have been made to 
increase the access of TVET programs throughout the country and make it affordable to all target groups, including gender, caste, ethnicity, and economically poor (CTEVT, 2018). Moreover, the term relevancy is probably the much used word in literature of TVET. Skills Development Policy, 2007 was the first TVET policy of Nepal which had recognized these issues together with other three priority areas like quality, integration and sustainable financing (Ministry of Education (MoE), 2007) ${ }^{1}$. The Technical and Vocational Education and Training (TVET) Policy, 2012 had also given equal emphasis to all of these areas (MoE, 2012), which is further continued in the Integrated Education Policy, 2019 (MoEST, 2019a). Moreover, ensuring inclusive and equitable access of quality education is one of the major goals of Sustainable Development Goal (SDG) which aims to support the efforts of Member States to enhance the relevance of their TVET systems and to equip all youth and adults with the skills required for employment, decent work, entrepreneurship and lifelong learning \{United Nations Educational, Scientific and Cultural Organization (UNESCO), 2016\}.

For a country like Nepal where each and every sector of economy is facing scarcity of technical human resources, the effective implementation of TVET policies to increase the quality and relevancy of TVET programs is the primary requirement of the country (Neupane, 2013). The subsequent TVET policies implemented in Nepal had therefore focused on all of these aspects of effective TVET system and management. Expansion of TVET institutions and programs is essential to increase the equitable access of TVET, but it is not sufficient in itself. Unless and until TVET programs devise certain quality standard and the curricula and training infrastructures which are relevant with the demand of the labour market, it will not work properly \{UNESCO, International Labour Organization (ILO), 2002 \}. During the last two decades, TVET sub-sector of Nepal has witnessed remarkable success in increasing the access of its programs throughout the country. However, progress towards equity and relevancy of programs is still debatable.

\section{Scope}

The scope of this paper is limited within the analysis of access and relevancy of presently available longterm TVET programs regulated by CTEVT and CEHRD. It only explores and considers the sector wise data of TVET programs, such as health, agriculture, engineering, tourism \& hospitality etc. but does not enter into program level analysis. Likewise, the analysis of equity and relevancy of short term TVET programs is also beyond the scope of this paper.

\section{Methodology}

Although, the paper is a review based paper, the quantitative analysis of micro data is also adopted as a major basis while preparing this paper. Mainly two data sets are used for the quantitative analysis. The first data set, which is used to analyze the status of access of TVET programs incorporates list of TVET institutes associated with CTEVT and CEHRD together with their address (Local Level), approved programs and enrolment capacity of these programs. In total, corresponding data of 1551 TVET institutes, including 1067 institutes associated with CTEVT and 484 institutes associated with CEHRD were included in the data set. The data obtained from the administrative record of these corresponding institutes were then migrated to computerized software named Statistical Programs for Social Science (SPSS) and further analysis was made. The long-term TVET capacity by province, district, local level and trade was first analyzed with the help of descriptive statistics.

Likewise, the second data set was also developed considering 77 districts as an analysis unit. In this data set, enrolment capacity of long term TVET programs, population, number of SEE graduates of 2017, economic establishment, persons engaged in those economic establishment were entered from different sources. The first variable 'enrolment

1 The name of then Ministry of Education (MoE) has changed now as Ministry of Education, Science and Technology (MoEST) 
capacity of long-term TVET programs' is considered as the indication of supply for the TVET programs whereas the later four variables are considered as the proxy of demand-side indicators. The district level enrolment capacity of long-term TVET programs is deducted from the first data set. Similarly, district wise SEE graduates' number is obtained from Education in Figure 2017 (MoEST, 2017), data of population is obtained from National Report of Population and Housing Census (2011) and district level economic establishments and corresponding number of persons engaged in those economic establishments were obtained from National Economic Census, 2018 (CBS, 2019a). The second data set is mainly used to explore and analyze the situation of relevancy of TVET programs at macro level.

Beside these two datasets, the literatures which have been central or pivotal to a particular topic of access and relevancy of TVET programs in Nepal are sufficiently reviewed in this paper. These literatures include journal articles, research reports, workshop proceedings, informative publications of government agencies and literatures available on-line regarding access and relevancy of TVET in general and case of Nepal in specific. Similarly, other informative documents were also collected and reviewed to explore the status of access and relevancy of TVET programs in Nepal.

\section{Analysis and Discussion}

In education, the term access typically refers to the ways in which educational institutions and policies ensure or at least strive to ensure that students have equal and equitable opportunities to take full advantage of their education (The Glossary of Education Reform, 2014). Since, TVET is considered as an integral part of education, the same concept also applies to TVET. Increasing access generally requires TVET system to provide additional services or remove any actual or potential barriers that might prevent some students to equitably participate in certain courses or programs (ibid).

\section{Expansion of TVET Programs}

At the time when CTEVT was established, there were only six technical schools throughout the country. Utterpani Technical School was the only technical school in the then Eastern Development Region (EDR) and Seti Technical School was the only technical school in the Far Western Development Region (FWDR). Increasing access to TVET programs for the needy population was the primary objective of the government. The plan of the then His Majesty's Government (HMG) to establish a technical school in each zone from Mechi to Mahakali had remained unfulfilled even after one decade (National Planning Commission (NPC), 1991).

Since the establishment of CTEVT in 1989, the rate of expansion of TVET institutions has been increasing uninterruptedly. In 1993, CTEVT had started to affiliate private technical schools to run TSLC ${ }^{2}$ programs and also started to grant affiliation to run diploma programs later in 2001. Similarly, since 2000 it started to run technical education in community high schools as an Annex Program ${ }^{3}$ (CTEVT, 2020). The technical stream education in community school which was started in 1993 under then Department of Education (DoE) ${ }^{4}$, further contributes on the number of technical schools. Ultimately, the number of long-term TVET providing institutes has reached to an all-time high (1551) at the end of the fiscal year 2019/20 (see chart 1).

The socio-economically backward communities have not been adequately included in the TVET subsectors for many years. The government had not sufficiently run the constituent schools which could provide opportunity to these groups of people under subsidized cost. Till 1999, there were only 13 constituent institutes to run long-term TVET Program (CTEVT, 1999). Likewise, the private institutes were not affordable for the students from lower economic class, (Dahal, 2020). In the meantime, the

\footnotetext{
2 The Technical School Leaving Certificate (TSLC) programs are now known as Pre-diploma programs.

3 The then 'Annex Program' is later known as TECS program.

4 The Department of Education(DoE) is now named Central for Education and Human Resource Development
} 
concept of technical education in community school (TECS) emerged which was expected to address both of these challenges. On one hand, TECS programs were assumed to be cost effective since it used the physical infrastructures and management system of community schools that has already been developed. Because of its social responsibility and non-profit nature, the target groups are expected to be subsidized (CTEVT, 2016).

\section{Chart 1}

Expansion of long-term TVET providing institute

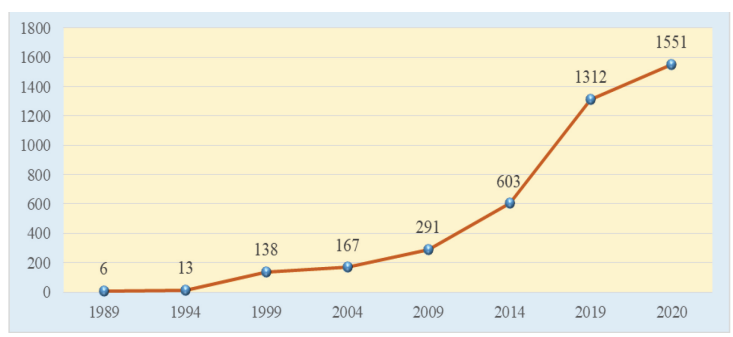

Source: CTEVT, 2020 ( Report of Skill Mapping Taskforce)

\section{Access of TVET Programs by Local Level}

Lamichhane, (2012) pointed out some barriers that hinders poor and disadvantaged groups to participate in the TVET programs. Two among the various barriers he pointed out were: TVET providers are far away from rural areas and the programs are unable to show clear linkage with employment. Likewise, Neupane, (2010) had further explored that $53 \%$ of long-term TVET institutes were concentrated in the Tarai region and 25\% in Kathmandu Valley. Among the rest 22\%, 19\% were in other hilly region (excluding Kathmandu Valley) and 3\% were in mountain region. These facts provide enough ground that till a decade earlier, large share of TVET providers were concentrated within district headquarter and other urban areas. Moreover, at the time when Right Honorable Prime Minister of Nepal, Mr. KP Sharma Oli, announced the commitment of his government to expand CTEVT affiliated institutes to each of the 753 local levels within two years. At that time, only 232 local levels had TVET institute to provide long-term TVET programs (MoEST, 2019b). Presently, the situation has changed, the local levels having TVET institutes has been increased to 635 , which is $84.32 \%$ of all 753 local levels (see Table 1). It is interesting to note that additional 403 local levels have got access to long term TVET providing institutes within the last two and half years. Although the backlash effect of that decision in quality of TVET programs cannot be overlooked, his announcement brought a paradigm shift in increasing access of TVET sector in Nepal, and more specifically in the rural part of the country.

Table 1

Local Level by institutional access of TVET

\begin{tabular}{lllll}
\hline SN & Provinces & Total local level* & $\begin{array}{l}\text { Local levels with } \\
\text { TVET institutes }\end{array}$ & Coverage rate \\
\hline 1 & Province No. 1 & 137 & 105 & 76.6 \\
2 & Province No. 2 & 136 & 103 & 75.7 \\
3 & Bagmati Province & 119 & 104 & 87.4 \\
4 & Gandaki Province & 85 & 71 & 83.5 \\
5 & Lumbini Province & 109 & 98 & 90.0 \\
6 & Karnali Province & 79 & 70 & 88.6 \\
7 & Sudurpaschim Province & 88 & 84 & 95.5 \\
& Total & 753 & 635 & 84.32 \\
\hline
\end{tabular}

Source: Analysis of microdata (data set 1); * Source: MoEST, (2017). Education in Figure 2017. 
If the proportion of local level with TVET institutes is compared by province, remarkable variation can be found. The TVET institutes in Sudurpaschim Province covers $95.5 \%$ of the local level followed by the Lumbini Province which is at the second position, where the TVET institutes cover $90 \%$ (98 of 109) of the local level. The corresponding percentage of local level with TVET institutes in Karnali, Bagmati, Gandaki Provinces and Province No. 1 are $88.6 \%, 87.4 \%, 83.5 \%$ and $76.6 \%$ respectively. It is unusual to note that among the seven provinces, Province 2 lies at the bottom with $75.7 \%$ local levels with TVET institutes, since this province is relatively in a comfortable position in terms of infrastructural development like roads and electricity. The reasons behind the lower institutional access of TVET programs in Province No. 2 may be due to easy access to road transportation making it easy to move to TVET institutes in the neighboring local levels and also due to easy access to Indian institutes because of the open border. Similarly, lower awareness on the importance of TVET may be another reason since literacy rate of this province $(50 \%)$ is lower in comparison to national standard (65\%) (MoEST, 2017).

The $84.32 \%$ coverage of local level does not mean that TVET programs have been accessed to $84.32 \%$ of citizens of the country. This is only a part of the story. Neither the area nor the population of these local levels are equal. Moreover, there may be notable variations of enrolment capacity, population and area among these local levels. So, institutional access of TVET in each of these local levels does not count the same. As per the population census, 2011, Kathmandu Metropolitan City is the local level with highest number of population $(975,753)$ whereas the population of Dolame Rural Municipality of Mustang District is the lowest with a population of 1,423 only (CBS, 2011).

The enrolment capacity of TVET programs among 77 districts gives certain indication regarding its equitable access. As explained in the methodology, data set 2 incorporates the enrolment capacity of TVET Programs, population, number of SEE graduates in 2017, number of economic establishments, and persons engaged in those economic establishments by districts. Descriptive statistics of some of these variables are presented in Table 2. As per this statistics, the average enrolment capacity of TVET in district level is 1,272.5. The higher value of standard deviation (1125) further suggests that there is large variation of enrolment capacity among the 77 districts. This status is further justified by the difference between the minimum number of enrolment capacity of district (40) and maximum number of enrolment capacity, which is 7,239 . Such types of variation can also be observed in other variables like, SEE graduates in 2017, economic establishment and persons engaged in those economic establishment. (See table 2).

Table 2

Descriptive statistics of variables regarding demand and supply of TVET

\begin{tabular}{lrrrrr}
\hline & N & Minimum & Maximum & Mean & Std. deviation \\
\hline SEE graduates in 2017 & 77 & 56.00 & 35581.00 & 6192.6234 & 5130.38206 \\
Enrolment capacity in TVET & 77 & 40.00 & 7239.00 & 1272.5584 & 1125.16067 \\
programs & 77 & 87.00 & 125047.00 & 11991.6364 & 15733.03378 \\
Economic establishment & 77 & 1695.00 & 590002.00 & 41928.0130 & 71065.81948 \\
Persons engaged in economic & & & & & \\
establishment & 77 & & & & \\
Valid N (list-wise) & & & & & \\
\hline
\end{tabular}

Source: Analysis of micro data (data set 2) 
Graduates of Secondary Education Examination (SEE) are the eligible population who can enroll in long- term TVET programs. In this line of reasoning, the ratio of enrolment capacity to SEE graduates helps to generate broader idea regarding the status of equitable access of TVET programs. So, another variable was created as "TVET capacity per 100 SEE graduates" in the same data set. Based on the analysis of this variable, the minimum ratio obtained from the analysis is 4.49 and maximum is 203.15. The mean value of this variable is obtained as 23.94 and standard deviation as 22.89. The higher value of standard deviation and wider gap between the minimum and maximum value also suggest that the opportunity to enroll in TVET programs are not equitable accessed to all parts of the country. Some parts of the country have higher access to TVET than others. (See table 2)

Table 3

Descriptive statistics on TVET capacity per 100 SEE Graduates

\begin{tabular}{llrrrr}
\hline & N & Minimum & Maximum & Mean & Std. Deviation \\
\hline $\begin{array}{l}\text { SEE graduates/TVET enrolment } \\
\text { capacity }\end{array}$ & 77 & 4.49 & 203.15 & 23.9409 & 22.89899 \\
Valid N (list-wise) & & & & & \\
\hline
\end{tabular}

Source: Analysis of Microdata (Data set 2)

Chart 2

Distribution of districts by enrolment opportunity in TVET

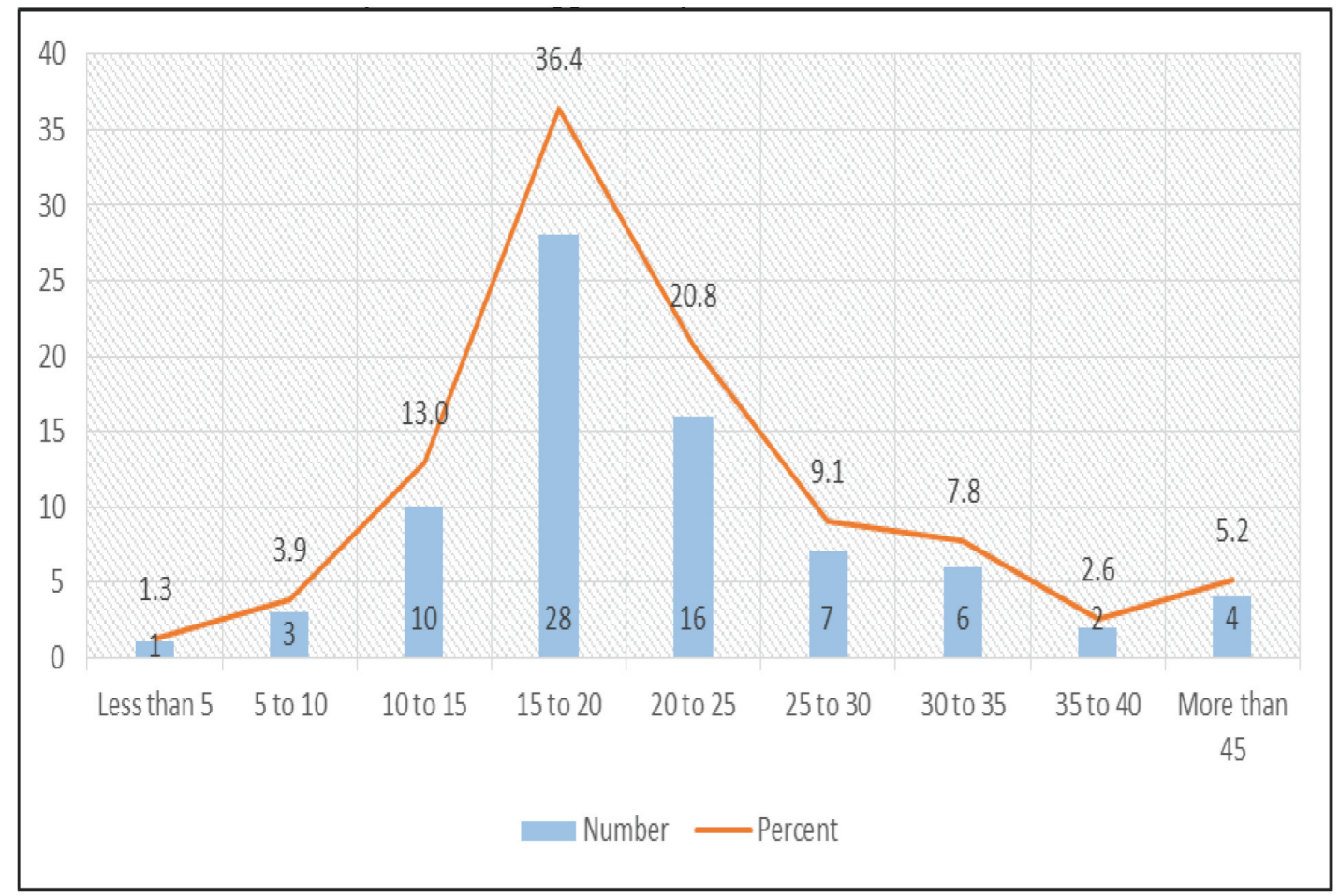

Source: Analysis of Microdata (Data set 2) 
Regarding the equitable access of TVET programs, we can broadly say that 24 out of 100 SEE graduates get an opportunity to enroll in TVET programs. The Chart 2 further shows the distribution of districts as per the range of enrolment capacity in TVET in terms of 100 SEE graduates. Of the total 77 districts, highest proportion $36.4 \%(\mathrm{~N}=28)$ of districts falls under the category of having 15 to 20 enrolment capacity per 100 SEE graduates followed by $20.8 \%$ districts falling under 20 to 25 enrolment capacity, $13 \%$ districts have under 10 to 15 enrolment capacity and so on (See chart 2). Moreover, data shows that almost $80 \%$ of the districts have between 10 to 30 SEE graduates enrolment capacity for every 100 SEE graduates in the TVET programs. It is obvious that the number of SEE graduates in the districts may not be constant overtime. Slight fluctuation on the number can be observed over time, so whether the variation can be acceptable or not is a million dollar question and requires further analysis. The analysis of correlation coefficient between TVET capacity, SEE graduates, and population can provide answer of that question to some extent.

Table 4

Correlation analysis on TVET Capacity, Population and SEE Graduates

\begin{tabular}{llll}
\hline & & $\begin{array}{l}\text { Enrollment capacity in } \\
\text { TVET programs }\end{array}$ & Population \\
\hline \multirow{2}{*}{ Population } & Pearson Correlation & $.862^{* *}$ & 1 \\
& Sig. (2-tailed) & .000 & \\
& $\mathrm{~N}$ & 77 & 77 \\
\hline \multirow{2}{*}{ SEE Graduates of 2017} & Pearson Correlation & $.931^{* *}$ & $.950^{* *}$ \\
& Sig. (2-tailed) & .000 & .000 \\
& $\mathrm{~N}$ & 77 & 77 \\
\hline
\end{tabular}

**. Correlation is significant at the 0.01 level (2-tailed).

Source : Analysis of micro data (data set 2)

Table 4 shows the results of correlation analysis among enrolment capacity on TVET Programs, Population and Number of SEE graduates together with other supplementary statistics. As per the data, there is significant positive correlation between each of these variables, however the degree of correlation is highest (.950) between population and SEE graduates followed by .931 between TVET capacity and SEE graduates and lowest 0.862 between TVET capacity and population.

The obtained correlation coefficient broadly suggest that the enrolment capacity of TVET programs are evenly distributed to all the district of the country to some extent. However, there is still sufficient room to make the distribution more equitable. If the correlation coefficient between the population and
SEE graduates (.950) is compared with the population and TVET enrollment capacity (.862), the significant difference between the obtained correlation coefficients suggest that the opportunity to technical education is not as easy as compared to general education. This factor should also be taken into account in the expansion of TVET programs in the future.

\section{Relevancy of TVET Programs}

Relevancy is one of the major factors that influences the effectiveness of TVET programs. However, it is not always easy to decide whether a program is relevant or not. Since in our context, $84.6 \%$ share is of informal employment whether it is in formal sector or informal sector (CBS, 2019b). It is obvious that none of the survey or census can perfectly capture 
the dynamics and dimensions of informal employment.

Attempt is made to analyze the relevancy of the TVET programs delivered in the country in broader scenario. As mentioned in methodology, enrolment capacity of long-term TVET program, which is considered as an indication of supply of TVET programs, is analyzed by the help of micro data set1. The TVET capacity is further categorized under five broader categories of occupational sectors as (a) Agriculture (b) Engineering (c) Health (d) Tourism and Hospitality and (e) Other service sectors. Similarly, the number of economic establishments and persons engaged in those economic establishment are the indication of demand since most of the formal employments are captured by these figures.

According to Nepal Labour Force Survey 2017-18, 7.08 million workers are currently working in the labour market. Out of them, 4.7 million are in the sub-sectors which are mainly related with more technical activities (CBS, 2019b). Eleven out of twenty-one sub-sectors can be considered to be under this category, which are agriculture; forestry and fishing; mining and quarrying; manufacturing; electricity, gas, steam and air conditioning supply; water supply; construction; transportation and storage; accommodation and food service activities; human health and social service activities and other services. Likewise, National Economic Census, 2018 has presented the disaggregated figure of economic establishments under the same categories (CBS, 2019a). These sub-sectors are again clustered under five broader headings of occupational sectors like agriculture, engineering, health, tourism and other service sector. For this re-categorization, agriculture, forestry and fishing is categorized as agriculture, human health and social service activities is categorized as health sector, accommodation and food service activity as tourism, and other service activities as other services. Similarly, the remaining six subsectors (Mining and quarrying; manufacturing; electricity, gas, steam and air conditioning supply, water supply; construction, and transportation and storage;) are categorized as engineering sector. The corresponding figures of existing workers from National Labour Force Survey, 2017-18 and economic establishments from National Economic Census, 2018 are subsumed accordingly under these five broader categories (CBS, 2019). (See table 5)

Table 5

Economic establishments, currently working labour force and Enrolment capacity by sector

\begin{tabular}{|c|c|c|c|c|c|c|c|}
\hline \multirow[t]{2}{*}{ SN } & \multirow[t]{2}{*}{ Occupational sector } & \multicolumn{2}{|c|}{$\begin{array}{c}\text { Economic } \\
\text { establishments } ¥\end{array}$} & \multicolumn{2}{|c|}{$\begin{array}{l}\text { Currently working } \\
\text { Labour Force v }\end{array}$} & \multicolumn{2}{|c|}{$\begin{array}{c}\text { Enrolment capacity in } \\
\text { TVET programs \# }\end{array}$} \\
\hline & & Number & Persons & Persons & $\%$ & Cap. & $\%$ \\
\hline 1 & Agriculture & 24,229 & 7.0 & $1,523,000$ & 31.8 & 34,124 & 34.8 \\
\hline 2 & Engineering & 116,073 & 33.3 & $2,567,000$ & 53.6 & 41,141 & 42.0 \\
\hline 3 & Health & 19,990 & 5.7 & 171,000 & 3.6 & 21,432 & 21.9 \\
\hline 4 & Tourism & 30,540 & 37.5 & 371,000 & 7.7 & 690 & 0.7 \\
\hline 5 & Other services & 57,514 & 16.5 & 156,000 & 3.3 & 600 & 0.6 \\
\hline & Total & 348,346 & 37.7 & $4,788,000$ & 100.0 & 97,987 & 100.0 \\
\hline
\end{tabular}

Sources: ¥ CBS,(2019a); v CBS, (2019b); \# Analysis of microdata (data set 1)

Table 5 shows that the Engineering sector occupies $42 \%$ share in the total enrolment capacity of TVET programs, whereas the share of this sector is $33.3 \%$ in terms of economic establishments and $53.3 \%$ in terms of currently working labour force. The former proportion is the indication of supply side status and later two proportions indicate the demand side status of TVET programs. Similarly, in agriculture sector, the corresponding share is $34.8 \%$ of enrollment capacity of TVET programs (as supply side) and 
$7.0 \%$ and $31.8 \%$ of economic establishment and currently working labour force (as demand sides) respectively.

Although slight mismatch can be observed between the supply and demand side proportions in the agriculture sector, this mismatch is considerable since data are taken from different sources and are not perfectly comparable. Similarly in engineering sector, the average of demand side proportions of two different sources, which is $43.45 \%$ (average of $33.3 \%$ and $53.6 \%$ ) almost matches with supply side proportions (42\%). Based on the analysis, sufficient evidences are not available to justify the mismatch between the demand and supply side of TVET in engineering and agriculture sector.

Unlike Engineering and Agriculture Sector, the discrepancy between supply and demand side proportions is found notably higher in health and tourism sector. In health sector, the proportion of supply side is found to be $(21.9 \%)$ whereas the proportions of the two demand side variables currently working labour force and economic establishments are $3.6 \%$ and $5.7 \%$ respectively. Similarly in tourism sector, the proportion of supply side variable is found to be $(0.7 \%)$ and the corresponding demand side variables are $7.7 \%$ and $37.5 \%$ respectively. Based on these notable discrepancies observed in the comparison, it can be concluded that TVET sector is under-capacitated in terms of tourism related programs whereas health sector can be taken as over capacitated sector.

Within the demand side data, the significant discrepancies is found in both thetourism and agriculture sector of currently working labour force, and economic establishments. The most probable reason behind this discrepancy is the variation of ratio between formal and informal employment. According to NLFS 2017/18, the ratio between formal and informal employment in agriculture and non-agriculture sector are 6:94 and 47:53 respectively
(CBS, 2019a). This ratio further suggests that the employment in tourism sector is mainly concentrated in registered enterprises/establishment whereas majority of agriculture related employment prevails outside the registered enterprises or establishments.

\section{Relevancy of Provincial Distribution of TVET Programs}

While analyzing the provincial distribution of enrolment capacity of TVET programs as per these occupational sectors, the pattern of distribution is not found to be as expected. Health related programs are found to be more concentrated in Province No. 1, Province No. 2, Bagmati Province and Lumbini Province. These four provinces occupy almost $85.4 \%$ of enrolment capacities of health related programs. If we analyze the distribution pattern separately for each province, large majority (43\%) of programs of Province No. 1 is related to engineering trade whereas significant proportion of programs are also related to agriculture (29\%) and health $(27 \%)$ trade. On the contrary, $61 \%$ programs of Karnali Province is related to the agriculture trade, $34 \%$ are related to the engineering trade whereas only $5 \%$ programs are related to the health trade (See table 6)

The trade and province wise distribution of enrollment capacity further supports the aforementioned analysis. The dominancy of engineering related programs is found in Province No. 1, Province No 2, Bagmati Gandaki and Lumbini Provinces which are comparatively known as industrialized provinces. Similarly, dominancy of agriculture related programs is found in less industrialized provinces like Karnali and Sudurpaschim Provinces, which are comparatively known as agriculture based provinces. The programs under health sector are found relatively in lower proportion in Karnali and Sudurpaschim Provinces. While analyzing the distribution patter of trade and programs by province, it seems rational on the basis of the economic activities of the provinces. 
Table 6

Trade wise and province wise enrolment capacity

\begin{tabular}{|c|c|c|c|c|c|c|c|c|c|c|c|c|}
\hline \multirow[t]{2}{*}{ SN } & \multirow[t]{2}{*}{ Province } & \multicolumn{2}{|c|}{ Agriculture } & \multicolumn{2}{|c|}{ Engineering } & \multicolumn{2}{|c|}{ Health } & \multicolumn{2}{|c|}{ Tourism } & \multicolumn{2}{|c|}{ Others } & \multirow{2}{*}{$\begin{array}{l}\text { Total } \\
\text { Cap. }\end{array}$} \\
\hline & & Cap. & $\%$ & Cap. & $\%$ & Cap. & $\%$ & Cap. & $\%$ & Cap. & $\%$ & \\
\hline 1 & Province No 1 & 4000 & 29 & 5840 & 43 & 3650 & 27 & 40 & 0.3 & 80 & 0.6 & 13610 \\
\hline 2 & Province No 2 & 2600 & 20 & 7272 & 56 & 3070 & 24 & 40 & 0.3 & 40 & 0.3 & 13022 \\
\hline 3 & Bagmati Province & 5640 & 24 & 9401 & 40 & 7852 & 33 & 360 & 1.5 & 200 & 0.9 & 23453 \\
\hline 4 & Gandaki Province & 3680 & 40 & 3632 & 40 & 1550 & 17 & 170 & 1.9 & 80 & 0.9 & 9112 \\
\hline 5 & Lumbani Province & 5844 & 34 & 7626 & 44 & 3740 & 22 & 40 & 0.2 & 120 & 0.7 & 17370 \\
\hline 6 & Karnali Province & 5680 & 61 & 3216 & 34 & 440 & 5 & & 0.0 & & 0.0 & 9336 \\
\hline \multirow[t]{2}{*}{7} & Sudurpaschim Province & 6680 & 55 & 4154 & 34 & 1130 & 9 & 40 & 0.3 & 80 & 0.7 & 12084 \\
\hline & Total & 34124 & 35 & 41141 & 42 & 21432 & 22 & 690 & 0.7 & 600 & 0.6 & 97987 \\
\hline
\end{tabular}

Source: Analysis of micro data (data set 1 )

\section{Relationship between Demand and Supply}

Attempt was made to analyze the relationship between enrolment capacity of TVET programs with other demand side variables - number of economic establishments and persons engaged in those economic establishment with the help of data set-2. Significant positive correlations are found in both case while running correlation analysis. The obtained correlation coefficient 0.866 between TVET enrolment capacity and economic establishment and 0.824 between TVET enrolment capacity and persons engaged in those economic establishment is found statistically significant at 0.01 level (See table 7). These correlation coefficients suggest strong positive correlation between the demand and supply of TVET programs. However, they are not close to perfectly correlation. These correlations are found to be weaker than the correlation between enrolment capacity and number of SEE graduates (0.931) (see table 7). This comparison further suggest that the enrolment capacity of TVET programs are more influenced by supply of students (Number of SEE graduates) rather than the demand of market (Establishment and employment).

Table 7

Correlation coefficients between demand and supply side indicators

\begin{tabular}{llcc}
\hline & & $\begin{array}{c}\text { Economic } \\
\text { establishments }\end{array}$ & $\begin{array}{c}\text { Persons engaged in } \\
\text { economic establishments }\end{array}$ \\
\hline Enrolment & Pearson Correlation & $.866^{* *}$ & $.824^{* *}$ \\
Capacity of TVET & Sig. (2-tailed) & .000 & .000 \\
& $\mathrm{~N}$ & 77 & 77 \\
\hline
\end{tabular}

**. Correlation is significant at the 0.01 level (2-tailed).

Source: Analysis of micro data (data Set 2)

\section{Productivity of Workers}

According to Nepal Labour Force Survey 2017-18, the average monthly income of the current working labour is NRs. 17,809 and considerable variation of income is found between informality (formal \& informal) and sectors (agriculture-non agriculture)
(CBS, 2019b). The average income of an individual who are engaged in formal employment in the agriculture sector earns NRs 14,197 per month whereas the corresponding income of an individual engaged in informal employment is NRs. 12,055. Unlike the considerable variation in agriculture 
sector, average income is found to be almost similar between informal and formal non agriculture sector. A person engaged in formal employment of nonagriculture sector earns (NRs. 18,942) almost same amount as those engaged in informal employment of non-agriculture sector (Rs.18,984) (CBS, 2019b).

Table 8

Monthly earning by occupational sector

\begin{tabular}{llr}
\hline SN & Sector & Average income \\
\hline 1 & Agriculture & 12,185 \\
2 & Engineering & 17,125 \\
3 & Health & 22,411 \\
4 & Tourism & 12,288 \\
5 & Other service sector & 19,406 \\
\hline & Average & 17,809
\end{tabular}

Source: CBS, (2019b) (Nepal Labour Force Survey, 201718

The income level of existing worker in five major trade is presented in table 8 . The income data was deducted by the same approach adopted as to generate table 4. Non-agriculture sector is justified as more productive sector than agriculture since comparatively productive workforces are engaged in this sector and relatively more advanced technologies are used. Comparatively, among the non-agriculture sector, more skilled and productive workforce are found in the health sector since the average income of person engaged in this sector is highest (NRs. 22,288) among the five sectors (See table 8). Similarly, other service sectors and engineering sector is also justified as productive sector. On the contrary, agriculture and tourism are the sectors in which productivity of workers are found to be relatively lower. According to human capital theory, the income variation among individuals is the factor of their investment in human capital. This means persons who invest more on education and skills have higher labour market outcome than those who invest less (Baker, 1962). Although some other factors (e.g. technological exploration, labour organization, uniqueness of occupation and wage trend) also slightly influence the income of individuals (Hasan,
2013), human capital components like skills and knowledge are the major determinants of individuals' income. These facts helps to conclude that TVET related investment in agriculture and tourism is found to be comparatively lower than others sectors of the economy. From the productivity point of view, it could be suggested that TVET programs or interventions are more required in tourism and agriculture trades to enhance overall productivity of country. Tourism and agriculture should therefore be the needy sector to carry out skill development activities in the future.

\section{Conclusion}

TVET sector of Nepal has achieved remarkable progress by expand the TVET institutes and programs after the establishment of CTEVT in 1989. The annual rate of expansion of TVET institutes since that date is observed as $43.34 \%$. Moreover, institutional access of TVET has been expanded to $83.4 \%$ of the local level till date. Although expansion of TVET institutes and program is necessary to increase the access of TVET Programs, but it is not sufficient in itself. Equitable access of TVET programs is crucial to get desired outcomes and sufficient attention should be paid to make the expansion equitable in every nook and corner of the country.

Twenty three out of hundred SEE graduates get the opportunity to be enrolled in the TVET programs in the present context of Nepal, however this opportunity is not found to be fairly distributed to every parts of the country. This opportunity is limited to less than 15 for some 15 particular districts but is higher than 30 for another 12 districts. Proper attention should therefore be paid towards the distribution of TVET programs equitably to all parts of the country.

The most challenging issue of the present TVET system is to mitigate the mismatch between presently available training programs and the need of the labour market. Broadly speaking, health related programs are justified as over accessed programs 
based on the analysis made in this paper whereas agriculture and tourism sectors are facing scarcity of skilled human resources as per the actual requirement. Moreover, tourism sector is revealed as a completely neglected sector in the aspect of skilled human resource development. On one hand, delivery of tourism related programs seems in the least priority of the TVET sector. On the other hand, the productivity of workers engaged in this sector is absolutely low. The lower productivity of workforce working in tourism and agriculture sectors further suggest higher need of skills training for the workers currently working in these sectors.

\section{References}

Baker, G. S. (1962). Investment in human capital : A theoretical analysis. Journal of Political Economy, 70(5),. 9-49. Retrieved from http:// www.jstor.org/sici?=0022-3808

Central Bureau of Statistics, (2011). National report of population and housing census, 2011. Kathmandu: Author

Central Bureau of Statistics, (2019a). National economic census, 2018. Kathmandu Nepal: Author Central Bureau of Statistics, (2019b). Report on the Nepal labour force survey, 2017 18. Kathmandu : Author

Council for Technical Education and Vocational Training, (1999). Development and expansion of technical education and vocational training in Nepal: Status, issues and future directions. Proceedings of the National workshop on developing TVET programs for meeting the workforce needs of Next Millennium, 16 July, 1999. Bhaktapur, Author

Council for Technical Education and Vocational Training, (2016). Council for technical education and vocational training: Annual report 2014/15. Bhaktapur: Author

Council for Technical Education and Vocational Training, (2020). Council for technical education and vocational training: Annual report 2018

\section{Bhaktapur: Author}

Council for Technical Education and Vocational Training, (2020). Council for technical education and vocational training: Annual report 2018/19. Bhaktapur: Author

Council for Technical Education and Vocational Training, (2016). CTEVT annual report 2014/15. Sanothimi, Bhaktapur: Author

Council for Technical Education and Vocational Training, (2018). Council for technical education and vocational training, Annual report 2016-17. Sanothimi, Bhaktapur: Author

Council for Technical Education and Vocational Training, (2020). The report presented by skill mapping taskforce -2020. (Unpublished copy).

Council for Technical Education and Vocational Training, (2020b). Report of skill mapping taskforce, 2020. Sanothimi, Bhaktapur: (Unpublished).

Dahal, S. K. (2020). Unequal access to TVET programmes in Nepal: Impact of neo-liberalism. Juournal of Education and Research 10(1) Pp. 81-99

Lamichhane, R. H. (2012). Factors affecting access of disadvantaged group to TVET. Technical and Vocational Education and Training Development Journal 12(1), Pp150-156.

Ministry of Education, (2007). Technical and vocational education and training, skill development policy 2007. Kathmandu: Author

Ministry of Education, (2012). Technical and vocational education and training policy, 2012: Kathmandu: Author

Ministry of Education, Science and Technology, (2017). Education in figures 2017- At a glance. Singadurbar, Kathmandu: Author

Ministry of Education Science and Technology, (2019a). Integrated education policy, 2019. 
Kathmandu: Author

Ministry of Education Science and Technology, (2019b). Status of technical and vocational Education and Training in Nepal 2019. Kathmandu, Nepal: Unpublished Infographics.

National Planning Commission, (1991). Eighth plan 1992-1997. Retrieved from: npc.gov.np/ images/category/eighth_eng.pdf

Neupane, B. M. (2010). Increasing access of technical and vocational education and training (TVET) programs and relevancy to the job market. Technical and Vocational Education and Training Development Journal 10(1), Pp161-167.

Neupane, M. S. (2013). Is investing in vocational training profitable: An analysis of rate of return. Technical and Vocational Education and Training Development Journal. 13(1), Pp.74-80.

The Glossary of Education Reform (2014). The glossary of education reform. Retrieved from https://www.edglossary.org/access/\#: : text= In $\% 20$ education $\% 2 \mathrm{C} \% 20$ the $\% 20$ term $\% 20$ access,full $\% 20$ advantage $\% 20$ of $\% 20$ their $\%$ 20education.

United Nations Educational Scientific and Cultural Organization, (2016). Strategy for technical and vocational education and training (2016-2021). UNESCO. Retrieved from : https://en.unesco.org/ sites/default/files/tvet.pdf

United Nations Educational Scientific Cultural Organization, International Labour Organization (2002). Technical and Vocational Education and Training for the twenty-first century. Paris, France. UNESCO, ILO 